Citation: Alcantara-Marte, Y. Y., Ramírez-Benítez, J. E., Arias-Lara, G. N., Velázquez-Vizcaíno, N. D., \& Alcantara-Marte, Y. Y. (2021). Effect of extraction ph and temperature on the physicochemical properties and pectin yield from mango peel (Mangifera indica L.). Agro Productividad. https://doi.org/ 10.32854/agrop.v14i12.2069

Editor in Chief: Dr. Jorge Cadena Iñiguez

Received: June 24, 2021. Accepted: November 5, 2021. Published on-line: December 20, 2021

This work is licensed under a Creative Commons Attribution-NonCommercial 4.0 International license.

\section{Effect of extraction ph and temperature on the physicochemical properties and pectin yield from mango peel (Mangifera indica L.)}

\author{
Alcantara-Marte, Yulisa Y. ${ }^{1}$; Ramírez-Benítez, José E. ${ }^{2 *}$; Arias-Lara, Gerson N. ${ }^{1}$; \\ Velázquez-Vizcaíno, Nelson D. ${ }^{1}$; Alcantara-Marte, Yanilka Y. ${ }^{1}$ \\ 1 Universidad ISA. Santiago de Los Caballeros, República Dominicana. Av. Pte. Antonio Guzmán Fernández \\ Km. 51/2, La Herradura. C.P. 51000. \\ 2 Universidad Autónoma de Campeche. San Francisco de Campeche, Campeche. Av. Ing. Humberto Lanz \\ Cárdenas S/N Col. Ex-hacienda Kalá. C. P. 24085. \\ * Correspondence: jeramire@uacam.mx
}

\begin{abstract}
Objective: To evaluate the effect of the $\mathrm{pH}$ and extraction temperature on the pectin yield from mango (Mangifera indica) peel, cultivar Banilejo, and its physicochemical properties.

Design/methodology/approach: Pectin extraction was done by acid hydrolysis, using hydrochloric acid and ethyl alcohol to precipitate and purify. A randomized design with a factorial arrangement was used, evaluating the effect of $\mathrm{pH}\left(1.5,2.0\right.$, and 2.5) and temperature $\left(70,80\right.$, and $\left.90^{\circ} \mathrm{C}\right)$ on the yield and quality of pectin. Quality was determined by measuring $\mathrm{pH}$, viscosity and moisture content, ash, methoxyls, and esterification degree. Their means were compared using Tukey's test at $95 \%$ confidence.

Results: The best results were obtained at $\mathrm{pH} 2.0$ and $80{ }^{\circ} \mathrm{C}$, reporting an $18.159 \%$ yield, $6.766 \%$ moisture, $2.630 \%$ ash, 0.085 Pa.s of viscosity, $26.307 \%$ methoxyl, and $64.753 \%$ esterification.

Study limitations/implications: The different treatment combinations demonstrate that $\mathrm{pH}$, ash, methoxyl content, and esterification degree vary as a function of the assessed $\mathrm{pH}$ and extraction temperatures; while viscosity, moisture and yield were not influenced by these variables.
\end{abstract}

Findings/conclusions: It is concluded that mango peel is a viable source to obtain quality pectin.

Keywords: Pectin, Mangifera indica, $\mathrm{pH}$, extraction temperature, peel.

\section{INTRODUCTION}

The Dominican Republic stands out for its geo-climatic conditions, suitable for fruit trees production. According to the FAO (2020a) mango continues to be one of the most traded tropical fruits worldwide and in 2019, along with guava and mangosteen, accounting for over a quarter of the total world tropical fruit trade. By 2029, global mango, mangosteens, and guavas production is expected to reach 72.8 million tons, annually increasing by $2.9 \%$ over the next decade (FAO, 2020b). 
Mango industrialization residues can be utilized. The peel accounts for 7 to $24 \%$ (wet basis) of the total weight of these fruits, according to the variety. Most of the peels are disposed of or used for animal feed. However, these constitute a potential source of pectins and polyphenols with market value and are therefore, exploitable (López, Sañudo, Aguilar, Rodríguez and Contreras, 2011; cited by Martínez, 2018).

Pectins are heterogeneous polysaccharides capable of absorbing large amounts of water and gelling, found in most vegetables and fruits, and in greater proportion in peels; specifically, in the primary cell walls and the middle lamella (Chasquibol, Arroyo and Morales, 2008; Picot-Allain, Ramasawmy, and Emmambux, 2020). Pectins production from fruits waste constitutes a reasonable and promising strategy to obtain natural biopolymers while contributing to recycling and promoting sustainable development (Dranca and Oroian, 2018).

There are different techniques for pectins extraction from plant tissues, either using physicochemical or enzymatic procedures. Their yield depends on the operating conditions, such as temperature extraction, extraction time, pH extraction (Pagan and Ibarz, 1999), extraction solvents, and adding chelating agents that help to release pectins from cell walls (Aldana, Aguilar, Contreras, Villaruel, Nevárez, 201 1). According to Púa, Barreto, Vallejo, and Ariza (2015), the most influential factor for pectins extraction is temperature, followed by time, whose variations considerably alter yield.

Therefore, the objective of this research was to evaluate the effect of $\mathrm{pH}$ and temperature extraction on the physicochemical properties and yield of pectins obtained from mango (Mangifera indica L.) peel, cultivar Banilejo.

\section{MATERIALS AND METHODS}

This research was conducted at ISA University, Santiago de los Caballeros, Dominican Republic.

\section{Raw material}

The main raw material was mango peels, cultivar Banilejo, acquired from local suppliers.

\section{Experimental design}

A completely randomized design, in a factorial arrangement, was used to evaluate the effect of $\mathrm{pH}\left(1.5,2.0\right.$, and 2.5) and temperature $\left(70,80\right.$, and $\left.90{ }^{\circ} \mathrm{C}\right)$ extraction on the yield and physicochemical properties of pectins. Nine treatments and three replicates were analyzed, a total of 27 experimental units.

\section{Description of the operations}

For the extraction of pectin, the methodology described by Cabarcas, Guerra, and Henao (2012) was followed and included the improvement recommendations stated at the end of their research. Mango peels were weighed, washed, and dried in a Quincy Lab Model 30 convection oven at $60{ }^{\circ} \mathrm{C}$ to a $10 \%$ moisture maximum. They were then crushed in an HC-500 multifunctional grain mill and sieved on a U.S.A. Standard Test Sieve ASTM E-11 $106 \mu \mathrm{m}$. Five parts of acidulated water, prepared with 37\% pure 
hydrochloric acid, were added to adjust the $\mathrm{pH}$ levels. The acid hydrolysis process was then initiated by placing the treatments in a Thermo Scientific model 2835 water bath with manual agitation, for 20 minutes. The resulting material was filtered through a cloth strainer and manually squeezed (pressing through the strainer) to separate the liquid from the solid material. The pectic solution was rapidly cooled $\left(<25{ }^{\circ} \mathrm{C}\right.$ to minimize pectins degradation); then $95 \%$ ethanol, corresponding to twice its volume, was added to induce pectin precipitation. It was left to stand for 60 minutes, then filtered and washed with $50 \%$ ethanol to eliminate the chlorides present. It was then placed in the drying oven at $60{ }^{\circ} \mathrm{C}$ until constant weight. The dried pectin was crushed, sieved, and analyzed.

\section{Variables evaluated}

The variables were analyzed at the Food Safety and Industrial Analysis Laboratory (LIAAI) at ISA University. These were: pH (AOAC 943.02, using a Consort R735 pH meter); viscosity (ISI, 2002), assessed with a Brookfield DV2T Viscometer, at $25^{\circ} \mathrm{C}$ and 10 RPM and reported in Pa.s); moisture (AOAC 925.09); ash (AOAC 923.03); methoxyl content (Gierschner, 1997); esterification degree (Owens and McGready, 1952); yield: the final weight of the pectin was related with the initial weight of the peel, following the formula:

$$
\operatorname{Yield}(D B)=\frac{\text { Pectins weight } \times 100}{\text { Mango peels weight }}
$$

\section{Statistical analysis}

The data obtained were evaluated by an analysis of variance (one-way ANOVA). Means were separated using Tukey's test $(\mathrm{P}<0.05)$. Statistix version 8.0 software was employed and the arithmetic means \pm standard deviation was used to present the results.

\section{RESULTS AND DISGUSSION}

The results of this research are summarized in Tables 1 and 2. Regard the $\mathrm{pH}$ of acidified water, the $\mathrm{pH}$ of the obtained pectin from mango peel ranged from 3.442 to 3.814, showing significant differences between treatments means (Table 1). Ferreira, Peralta, and Rodríguez (1995) reported the same pattern, where an increase in the $\mathrm{pH}$ of pectin was found when using higher $\mathrm{pH}$ solutions, which could be because alkalinity is inversely proportional to the level of hydrogen ions: as $\mathrm{pH}$ levels increase, $\mathrm{H}^{+}$ions decrease, resulting in higher $\mathrm{pH}$ (Cabarcas et al., 2012).

The studied temperature variations $\left(70,80,90^{\circ} \mathrm{C}\right)$ produced $\mathrm{pH}$ from 3.631 to 3.673, with no difference between the treatments means (Table 1). Paredes, Hernández, and Canizares (2015), in their research about pectin extraction from guava hulls at different maturity stages, at 90 and $95^{\circ} \mathrm{C}$, obtained similar values to reported here, corresponding to 4.05-4.25 (green hulls), 3.8-4.37 (pinto hulls) and 3.9-4.1 (ripe hulls), with no significant differences in relation to the assessed extraction temperatures.

The results of $\mathrm{pH}$ on the interaction between extraction $\mathrm{pH}$ and extraction temperature are shown in Table 2, with values ranging from 3.41 to 3.83, with the treatments being 
Table 1. Effect of $\mathrm{pH}$ and temperature extraction on the yield and physicochemical properties of pectins from mango (Mangifera indica L.) peel cultivar Banilejo.

\begin{tabular}{|c|c|c|c|c|c|c|c|c|}
\hline & & $\mathrm{pH}$ & $\begin{array}{c}\text { Viscosity } \\
\text { (Pa.s) }\end{array}$ & $\begin{array}{c}\text { Humidity } \\
(\%)\end{array}$ & $\begin{array}{c}\text { Ashes } \\
(\%)\end{array}$ & $\begin{array}{c}\text { Methoxyls } \\
(\%)\end{array}$ & $\begin{array}{c}\text { Esterification } \\
(\%)\end{array}$ & $\begin{array}{c}\text { Pectin yield } \\
(\%)\end{array}$ \\
\hline \multirow{3}{*}{$\mathrm{pH}$} & 1.5 & $3.442 \pm 0.049^{c}$ & $0.069 \pm 0.008^{b}$ & $6.768 \pm 0.681^{a}$ & $2.880 \pm 0.125^{\mathrm{a}}$ & $26.536 \pm 0.243^{\mathrm{a}}$ & $66.897 \pm 2.235^{\mathrm{b}}$ & $16.188 \pm 1.736^{\mathrm{a}}$ \\
\hline & 2.0 & $3.706 \pm 0.046^{b}$ & $0.080 \pm 0.012^{a b}$ & $6.808 \pm 0.389^{a}$ & $2.744 \pm 0.272^{\mathrm{a}}$ & $26.434 \pm 0.292^{\mathrm{a}}$ & $67.141 \pm 2.628^{b}$ & $17.206 \pm 1.131^{\mathrm{a}}$ \\
\hline & 2.5 & $3.814 \pm 0.047^{\mathrm{a}}$ & $0.083 \pm 0.013^{\mathrm{a}}$ & $6.574 \pm 0.961^{a}$ & $2.883 \pm 0.161^{\mathrm{a}}$ & $26.040 \pm 0.111^{b}$ & $70.241 \pm 1.160^{\mathrm{a}}$ & $16.142 \pm 1.549^{\mathrm{a}}$ \\
\hline \multirow{3}{*}{ 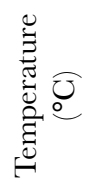 } & 70 & $3.673 \pm 0.148^{\mathrm{a}}$ & $0.073 \pm 0.009^{a}$ & $6.623 \pm 0.522^{\mathrm{a}}$ & $3.002 \pm 0.194^{\mathrm{a}}$ & $26.432 \pm 0.306^{\mathrm{a}}$ & $69.012 \pm 2.138^{\mathrm{a}}$ & $16.642 \pm 1.404^{\mathrm{a}}$ \\
\hline & 80 & $3.631 \pm 0.171^{\mathrm{a}}$ & $0.080 \pm 0.008^{\mathrm{a}}$ & $6.529 \pm 0.399^{a}$ & $2.751 \pm 0.132^{b}$ & $26.226 \pm 0.195^{\mathrm{a}}$ & $66.738 \pm 2.617^{b}$ & $16.739 \pm 1.382^{\mathrm{a}}$ \\
\hline & 90 & $3.658 \pm 0.193^{\mathrm{a}}$ & $0.080 \pm 0.018^{\mathrm{a}}$ & $6.993 \pm 1.003^{\mathrm{a}}$ & $2.754 \pm 0.167^{b}$ & $26.352 \pm 0.394^{\mathrm{a}}$ & $68.529 \pm 2.534^{\mathrm{ab}}$ & $16.155 \pm 1.845^{\mathrm{a}}$ \\
\hline
\end{tabular}

Values placed after the \pm symbol indicate the standard deviation between the means. Different letters in the same column indicate difference $(\mathrm{P}<0.05)$ between the means of the evaluated treatments.

Table 2. Effect of the interaction of $\mathrm{pH}$ and temperature extraction on the yield and physicochemical properties of pectins from mango (Mangifera indica L.) peel cultivar Banilejo.

\begin{tabular}{|c|c|c|c|c|c|c|c|c|}
\hline 竌 & 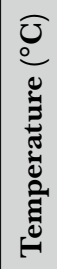 & $\frac{\pi}{2}$ & 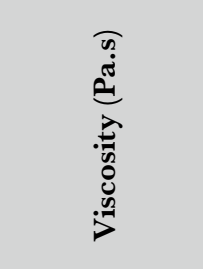 & 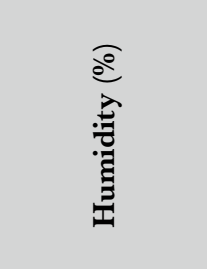 & $\frac{\frac{0}{2}}{\frac{e}{n}}$ & 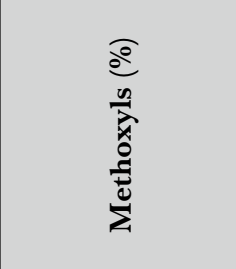 & 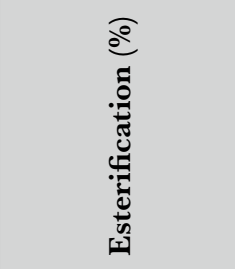 & 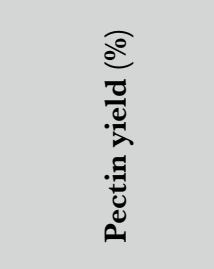 \\
\hline \multirow{3}{*}{1.5} & 70 & $3.490 \pm 0.062^{\mathrm{c}}$ & $0.072 \pm 0.012^{\mathrm{a}}$ & $6.452 \pm 0.382^{\mathrm{a}}$ & $2.913 \pm 0.158^{\mathrm{abc}}$ & $26.493 \pm 0.313^{\mathrm{ab}}$ & $68.980 \pm 2.304^{\mathrm{ab}}$ & $16.559 \pm 0.982^{a}$ \\
\hline & 80 & $3.427 \pm 0.021^{c}$ & $0.073 \pm 0.003^{\mathrm{a}}$ & $6.677 \pm 0.446^{\mathrm{a}}$ & $2.850 \pm 0.173^{\mathrm{abc}}$ & $26.370 \pm 0.092^{a b}$ & $66.030 \pm 2.018^{a b}$ & $16.128 \pm 1.366^{\mathrm{a}}$ \\
\hline & 90 & $3.410 \pm 0.010^{c}$ & $0.062 \pm 0.002^{\mathrm{a}}$ & $7.160 \pm 1.058^{\mathrm{a}}$ & $2.877 \pm 0.063^{\mathrm{abc}}$ & $26.743 \pm 0.144^{\mathrm{a}}$ & $65.680 \pm 0.858^{b}$ & $15.877 \pm 2.976^{\mathrm{a}}$ \\
\hline \multirow{3}{*}{2.0} & 70 & $3.723 \pm 0.045^{\mathrm{ab}}$ & $0.071 \pm 0.004^{\mathrm{a}}$ & $7.180 \pm 0.127^{\mathrm{a}}$ & $3.043 \pm 0.273^{\mathrm{ab}}$ & $26.640 \pm 0.305^{\mathrm{a}}$ & $67.247 \pm 1.519^{a b}$ & $16.371 \pm 0.431^{\mathrm{a}}$ \\
\hline & 80 & $3.667 \pm 0.051^{b}$ & $0.085 \pm 0.005^{\mathrm{a}}$ & $6.766 \pm 0.269^{a}$ & $2.630 \pm 0.035^{\mathrm{bc}}$ & $26.307 \pm 0.131^{\mathrm{ab}}$ & $64.753 \pm 1.799^{b}$ & $18.159 \pm 0.571^{a}$ \\
\hline & 90 & $3.727 \pm 0.021^{\mathrm{ab}}$ & $0.085 \pm 0.020^{\mathrm{a}}$ & $6.477 \pm 0.374^{\mathrm{a}}$ & $2.560 \pm 0.121^{\mathrm{c}}$ & $26.357 \pm 0.367^{\mathrm{ab}}$ & $69.423 \pm 2.387^{\mathrm{ab}}$ & $17.086 \pm 1.476^{\mathrm{a}}$ \\
\hline \multirow{3}{*}{2.5} & 70 & $3.807 \pm 0.032^{\mathrm{a}}$ & $0.075 \pm 0.014^{\mathrm{a}}$ & $6.237 \pm 0.443^{a}$ & $3.050 \pm 0.180^{\mathrm{a}}$ & $26.163 \pm 0.065^{\mathrm{ab}}$ & $70.810 \pm 1.065^{\mathrm{a}}$ & $16.996 \pm 2.535^{\mathrm{a}}$ \\
\hline & 80 & $3.800 \pm 0.078^{\mathrm{a}}$ & $0.081 \pm 0.010^{\mathrm{a}}$ & $6.142 \pm 0.159^{\mathrm{a}}$ & $2.773 \pm 0.029^{\mathrm{abc}}$ & $26.000 \pm 0.092^{b}$ & $69.430 \pm 1.595^{\mathrm{ab}}$ & $15.930 \pm 0.935^{\mathrm{a}}$ \\
\hline & 90 & $3.837 \pm 0.021^{\mathrm{a}}$ & $0.091 \pm 0.013^{\mathrm{a}}$ & $7.341 \pm 1.464^{\mathrm{a}}$ & $2.827 \pm 0.078^{\mathrm{abc}}$ & $25.957 \pm 0.032^{b}$ & $70.483 \pm 0.383^{\mathrm{a}}$ & $15.501 \pm 0.719^{a}$ \\
\hline
\end{tabular}

Values placed after the \pm symbol indicate the standard deviation between the means. Different letters in the same column indicate difference $(\mathrm{P}<0.05)$ between the means of the evaluated treatments.

statistically different. The highest value (3.83) is above that reported by Beltrán, Díaz and Sáenz (2011), for commercial pectin derived from citrus products (3.5).

As for the viscosity of mango peel pectins, it is affected by variation $\mathrm{pH}$ extraction levels, reporting values between 0.069 and $0.082 \mathrm{~Pa}$.s. This shows a clear tendency to decrease as $\mathrm{pH}$ is lowered, which is consistent with the research by Alfonso (2010) about the rheological behavior of pectins, where treatments at $\mathrm{pH} 1.2$ and $70^{\circ} \mathrm{C}$ resulted in $0.026-0.032 \mathrm{~Pa} . \mathrm{s}$, while treatments with higher $\mathrm{pH}$ showed higher values.

The viscosity of mango peel pectin was not affected by the variation of the studied temperatures nor with the $\mathrm{pH}$-temperature interaction, so these results will not be discussed. 
Tables 1 and 2 show that the independent factors and their interaction do not influence the moisture content of mango peel pectins. Pectin is a substance with a high-water retention capacity, so moisture content is an important parameter for its commercialization, whose maximum limit is officially set at $12 \%$ (Food Chemical Codex, 2003). The moisture results in the present research are within the established limits and are similar to those obtained by Ferreira (2007) in pectin from tropical fruits (1.10 to 5.63\%); Cabarcas et al. (2012) in pectin from banana peels (1-12\%) and 11.04 and 2.10\% by Vásquez et al. (2008), when using $\mathrm{pH} 2$ and 3, respectively.

Another evaluated response variable was the ash content of the pectin. Table 1 shows that, by modifying the $\mathrm{pH}$ of the solution, pectin with 2.74 to $2.88 \%$ ash was obtained, with no significant differences between their means. These values are similar to those reported by Normah and Hasnah (2000) and Corona, Díaz, Páez, Ferrer, Mármol and Ramones (2012), 3.40\% in kiwifruit and 2.04\% in parchita peel, respectively.

The extraction temperature influenced the ash content of the studied pectin, between $2.75 \%$ to $3.00 \%$. These results differ from those reported by Lliuyacc (2018) in pectin from Serrano tumbo peel, where despite finding no significant differences in the assessed temperatures $\left(60{ }^{\circ} \mathrm{C}, 64{ }^{\circ} \mathrm{C}, 70{ }^{\circ} \mathrm{C}, 76{ }^{\circ} \mathrm{C}\right.$, and $\left.80{ }^{\circ} \mathrm{C}\right)$, found the highest ash content between $76^{\circ} \mathrm{C}$ to $80^{\circ} \mathrm{C}$, the lowest at $60^{\circ} \mathrm{C}$.

The interaction between $\mathrm{pH}$ and extraction temperature (Table 2) also affected the ash content of pectin, with values from 2.56 to $3.05 \%$; being similar to those obtained by Cabarcas et al. (2012) in banana peel pectin (0.9-3.5\%) and different from those reported by Lliuyacc (2018), which range from 5.755 to $23.772 \%$.

Methoxyl values were affected by the extraction $\mathrm{pH}$, ranging from $26.04 \%$ to $26.54 \%$. It was observed that the lower the $\mathrm{pH}$, the higher the methoxyl content, which differs from the findings of Vásquez et al. (2008), where methoxyl content decreased with decreasing $\mathrm{pH}$, showing $1.47 \%$ at $\mathrm{pH} 2.0$ (66\% lower compared to that obtained at $\mathrm{pH} 3.0)$. These data are consistent with the findings of Pagan and Ibarz (1999), who observed that high temperatures and low $\mathrm{pH}$ seem to favor pectin demethylation.

The studied temperature levels resulted in pectins with values between 26.226 and $26.432 \%$ of methoxyl, no significant differences between the means are observed. As the extraction temperature increases, the methoxyl content decreases. Lliuyacc (2018) indicates that this may be because increasing the time and extraction temperature increases yield, but the methoxyls percentage reduces due to increased esters hydrolysis in the methoxylated carboxyl groups and directly relates to the pectins quality.

By evaluating the interaction between $\mathrm{pH}$ and extraction temperature, methoxyl values ranging from 25.957 to $26.743 \%$ were found (in the $\mathrm{pH} 1.5$ treatment at $90{ }^{\circ} \mathrm{C}$ ), showing statistical differences. These findings are concurring with those by Alfonso (2010), who showed that the temperature-pH interaction produces a higher percentage when the temperature is at maximum and $\mathrm{pH}$ at minimum. The results in this research were superior to those obtained by Cabarcas et al. (2012) and Vásquez et al. (2008) in banana peel pectin and to those obtained by Ferreira (2007) in tropical fruit pectins, being these of low methoxyl in their respective research. 
Table 1 also presents the effect of the $\mathrm{pH}$ of the solution on the pectin's esterification degree (ED), where values from 66.897 to $70.241 \%$ were observed, with a significant difference between the evaluated means. These results show that increasing the $\mathrm{pH}$ produces an increase in ED, which is consistent with the values obtained by Flores, Mariños, Rodríguez, and Rodríguez (2014), who, by increasing the $\mathrm{pH}$ from 2 to 3, obtained a 53.8 to $65 \%$ increase in ED. They also concur with the data obtained by Rodríguez and Rodríguez (2018) in their research on the concentration of citric acid in the quality of pectin's, where, when using $0.2 \%$ obtained $86.51 \% \mathrm{ED}$, while when using high concentrations, the results were lower.

The ED of mango peel pectins is also affected by the extraction temperature, resulting in values between 66.738 and $69.012 \%$. The pectin with the highest ED was the one extracted at $70{ }^{\circ} \mathrm{C}$, probably because moderate temperatures allow reaching higher esterification degrees.

The results of the ED in relation to the $\mathrm{pH}$-extraction temperature interaction are shown in Table 2, with values ranging from 64.75 to $70.81 \%$, the treatments being statistically different. These data are lower than those reported by Ferreira (2007) for tropical fruit pectins (84.2-93.5\%). Except for the treatments corresponding to $\mathrm{pH} 2$, by combining low $\mathrm{pH}$ values and temperatures, better results are obtained. This is consistent with the research by Flores et al. (2014), whereby using $\mathrm{pH}$ between 1 and 1.5 and temperature between 70 and $80^{\circ} \mathrm{C}$, the $\mathrm{ED}$ was higher than $80 \%$, concluding that low $\mathrm{pH}$ and moderate temperatures are needed to achieve high ED, indicating good pectin quality (Baltazar, Carbajal, Baca and Salvador, 2013).

The yield of mango peel pectins was not affected by the $\mathrm{pH}$ or extraction temperature (Table 1), nor by the combination of these factors (Table 2). Regard the $\mathrm{pH}$, the values were between 16.142 and $17.206 \%$. There are divergences because of the effect of the extraction $\mathrm{pH}$ on the results of the final pectin, since research, such as that of Flores et al. (2014) showed a tendency that at constant extraction times, the decrease in $\mathrm{pH}$ produces an increase in the yield of extracted pectin. Still, Lliuyacc (2018) reports that the higher the $\mathrm{pH}$, the higher the yield. In the present research, the highest yield was obtained at $\mathrm{pH} 2$.

The evaluated temperatures resulted in yields between 16.155 and $16.739 \%$, without significant changes; being numerically higher the one obtained at $80^{\circ} \mathrm{C}$. This concurs with that reported by Flores et al. (2014), in French lemon peel, who obtained the best values at temperatures between 73 and $80^{\circ} \mathrm{C}$. According to Púa et al. (2015), the most influential factor in pectin extraction is temperature, since high temperatures increase the hydrolysis of protopectin (insoluble) bonds, converting it into water-soluble pectin.

Regard the interaction between $\mathrm{pH}$ and extraction temperature, yields from 15.501 to $18.159 \%$ were found. Although the means are statistically equal, the treatment with the highest yield (18.159\%) was the one extracted at $\mathrm{pH} 2.0$ and $80^{\circ} \mathrm{C}$. These results are close to the highest levels of commercial pectin extraction, such as that from sunflower, with $25 \%$ obtained by Rojas, Perea, and Stashenko (2008), cited by Baltazar et al. (2013). Similarly, Cabarcas et al. (2012) obtained a maximum yield on a dry basis of $23.06 \%$ when extracting pectin from banana peels at $\mathrm{pH} 1.5$ and $80{ }^{\circ} \mathrm{C}$ and its minimum yield at a temperature of $73^{\circ} \mathrm{C}$ and $\mathrm{pH} 2.7$. 


\section{CONGLUSIONS}

The results show that $\mathrm{pH}$, ash, methoxyl content, and esterification degree vary according to the applied $\mathrm{pH}$ and extraction temperatures, while viscosity, moisture, and yield are not influenced by these variables. The best results were obtained when using the $\mathrm{pH} *$ temperature combination of $2.0^{*} 80^{\circ} \mathrm{C}$. No difference was observed between the yields of the evaluated treatments, but numerically, the highest yield was obtained when using the $\mathrm{pH}$ *temperature combination $2.0 * 80{ }^{\circ} \mathrm{C}$, which corresponds to the intermediate assessed values.

\section{REFERENGES}

Aldana Villaruel, D., Aguilar González, C., Contreras Esquivel, J., Nevárez Moorillón, G. (2011). Moléculas Pécticas: Extracción y su Potencial Aplicación como Empaque. Tecnociencia Chihuahua, 5(2), 76 -82.

Alfonso, E. (2010). Estudio del Comportamiento Reológico de las Pectinas con Diferente Grado Galacturonico Obtenida a partir de Citrus paradisi (GRAY FRUIT). Disponible en: http://ri.ues.edu.sv/471

AOAC International. (2012). Official Methods of Analysis of AOAC International (W. George \& Jr. Latimer, Eds.; Vol. 2).

Baltazar, R., Carbajal, M., Baca, N., Salvador, D. (2013). Optimización de las Condiciones de Extracción de Pectina a partir de cáscara de Limón Francés (Citrus medica) Utilizando la Metodología de Superficie de Respuesta.

Beltrán, X., Díaz, R., Sáenz, G. (2011). Extracción y Caracterización de Pectinas. Disponible en: https:// es.slideshare.net/xilberferbeltranfernandez/extraccion-de-pectina

Cabarcas, E., Guerra, A., Henao, C. (2012). Extracción y Caracterización de Pectina a partir de Cáscaras de Plátano para Desarrollar un Diseño General del Proceso de Producción. http://190.242.62.234:8080/ jspui/bitstream/1 1227/109/1/Trabajo\%20de\%20grado-Extraccion\%20y\%20caracterizacion\%20de\%20 pectina\%20apartir\%20de\%20cascaras\%20de\%20platano\%20para\%20desarrollar\%20un\%20dise \%C3$\%$ B 1o\%20genera $1 . p d f$

Chasquibol, N., Arroyo, E., Morales, J. (2008). Extracción y Caracterización de Pectinas Obtenidas a Partir de Frutos de la Biodiversidad Peruana. Ingeniería Industrial, 26, 175-199.

Corona, M., Díaz, A., Páez, G., Ferrer, J., Mármol, Z., Ramones, E. (2012). Extracción y Caracterización de Pectina de la Corteza de Parchita. Revista De La Facultad De Agronomía De La Universidad Del Zulia, $13(6)$.

Dranca, F., Oroian, M. (2018). Extraction, purification and characterization of pectin from alternative sources with potential technological applications. Food Research International, 113. 327-350. Doi: 10.1016/j. foodres.2018.06.065

FAO. (2020a). Análisis de Mercado de las Principales Frutas Tropicales 2019. http://www.fao.org/3/cb0834es/ CB0834ES.pdf

FAO. (2020b). Análisis del Mercado de las Principales Frutas Tropicales. Panorama General de Febrero 2020. Disponible en: http://www.fao.org/3/ca9213es/ca9213es.pdf

Ferreira, S. (2007). Pectinas: Aislamiento, Caracterización Y Producción A Partir de Frutas Tropicales y de Los Residuos de su Procesamiento Industrial. Universidad Nacional de Colombia, Bogota, Colombia.

Ferreira, S., Peralta, A., Rodríguez, G. (1995). Obtención y Caracterización de Pectina a partir de Desechos Industriales del Mango (cáscara). Revista Colombiana de Ciencias Químico Farmacéuticas, 24(1), 29-34.

Flores, R., Mariños, D., Rodríguez, N., Rodríguez, D. (2014). Optimización de las Condiciones de Extracción de Pectina a partir de Cáscara de Limón Francés (Citrus medica) Utilizando la Metodología de Superficie de Respuesta. Agroindustrial Science, 3(2), 77-89.

Food Chemical Codex. (2003). Monograph on Pectin (5th ed.). Nathional Academy of Sciences.

Gierschner, K. (1997). Pectin and Pectic Enzymes in Fruit and Vegetable Technology. Gordian, 81, 171-177.

ISI (International Starch Institute). (2002). Determination of Viscosity of Starch by Brookfield. Disponible en: http://www.starch. dk/ isi/methods/index.htm.

Lliuyacc Laurente, R. (2018). Efecto de la Temperatura, Tiempo y ph en el Rendimiento de Extracción de Pectina en Cáscara de Tumbo Serrano (Passiflora tripartita L.). Universidad Nacional de Huancavelca, grado de ingeniería, Avenida Agricultura 319-321, Paturpampa 09001, Perú.

López Martínez, N., Sañudo Barajas, J., Aguilar, C., Rodríguez Herrera, R., Contreras Esquivel, J. (2011). Pectina de Mango: Perspectivas para su Extracción. Revista de Divulgación Científica Humanistica Y de Tecnología Ciencia-Cierta, 27. 
Martínez, J. (2018). Evaluación de Pectinas Cítricas de Toronja (Citrus paradisi var. Star Ruby) y Mandarina (Citrus reticulata blanco var. Tangerina) como Agentes Encapsulantes de Extractos Acuosos de Stevia rebaudiana bertoni. Ciencia y Tecnología para el Desarrollo Sostenible, A.C. Tablaje catastral 31264 km 5.5, carr. Sierra Papacal-Chuburna Puerto Parque científico tecnológico de Yucatán, Mérida, Yucatán, México grado de maestria.

Normah, O., Hasnah, K. (2000). Pectin Content of Select Local Fruits by Products. Journal of Tropical Agriculture and Food Science, 28(2), 195-201.

Owens, H., McCready, R. (1952). Methods used at the Western Regional Research Laboratory for the Extraction and Analysis of Pectic Material. Dept. Agr.

Pagan, J., Ibarz, A. (1999). Extraction and Rheological Properties of Pectin from Fresh Peach Pomace. Journal of Food Engineering, 39(2), 193-201. Doi: 10.1016/S0260-8774(98)00163-0

Paredes, J., Hernández, R., Canizares, A. (2015). Efecto del Grado de Madurez sobre las Propiedades Fisicoquímicas de Pectinas Extraídas de Cascos de Guayaba (Psidium guajava L.). Idesia (Arica) . 33 (3). 35-41. Doi: 10.4067/S0718-34292015000300006

Picot-Allain, M., Ramasawmy, B., Emmambux, M. (2020). Extraction, Characterisation, and Application of Pectin from Tropical and Sub-Tropical Fruits: A Review. Food Reviewes International, 1525-6103. Doi: 10.1080/87559129.2020.1733008

Púa, A., Barreto, G., Ariza, C. (2015). Extraccion y Caracterizacion de la Pectina Obtenida a partir de la Cascara de Limón Tahiti (citrus $\times$ latifolia) en dos Estados de Maduración. Limentech Ciencia y Tecnología Alimentaria, 13(2), 180-194.

Rodríguez, A., Rodríguez, S. (2018). Influencia de la Concentración del Ácido Cítrico en la Calidad de Pectinas Obtenidas a partir de Cáscaras de Mandarina, Maracuyá y Limón. Universidad Nacional de de Trujillo, Facultad de ingeniería química, Av. Juan Pablo II, Trujillo 13011, Perú, grado de ingeniería.

Rojas, J., Perea, A., Stashenko, E. (2008). Obtención de Aceites Esenciales y Pectinas a Partir de Subproductos de Jugos Cítricos. Vitae. 16 (1). 5-11.

Vásquez, R., Ruesga, L., D’addosio, R., Marín, M. (2008). Extracción de Pectina a partir de la Cáscara de Plátano (Musa AAB, subgrupo plátano) Clon Hartón. Revista de La Facultad de Agronomía, 25(2), 318-333. 